\title{
VEGFR2/PDGFR/c-Kit/Flt-3 Inhibitor SU014813
}

National Cancer Institute

\section{Source}

National Cancer Institute. VEGFR2/PDGFR/c-Kit/Flt-3 Inhibitor SU014813. NCI Thesaurus. Code C61507.

An orally-active, tyrosine kinase receptor inhibitor with potential antitumor activity.

SU014813 binds to and inhibits the phosphorylation of vascular endothelial growth factor receptor 2 (VEGFR2), platelet-derived growth factor receptor (PDGFR) alpha and beta, cKit and Fms-related tyrosine kinase 3 (Flt-3). This leads to an inhibition of cellular proliferation and angiogenesis and an induction of apoptosis. 